\title{
Analisis Kesesuaian Lahan Kering Kabupaten Bima Untuk Produksi Kedelai
}

\author{
Tribhuana Tungga Dewi', Taslim Sjah', Sukartono', Bambang Dipokusumo', Nani Herawati² \\ 1Pasca Sarjana Program Study Lahan Kering, Fakultas Pertanian, Universitas Mataram. \\ ²Balai Pengkajian Teknologi Pertanian Nusa Tenggara Barat \\ taslim.sjah@unram.ac.id
}

INFO ARTIKEL
Riwayat Artikel:
Diterima: 13-12-2020
Disetujui: 20-02-2021

Kata Kunci:

Kesesuaian Lahan

Lahan Kering

Pemetaan Lahan

Kedelai

Bima

\begin{abstract}
ABSTRAK
Abstrak: Provinsi Nusa Tenggara Barat (NTB), adalah salah satu dari 3 provinsi di Indonesia sebagai penghasil komoditas kedelai. Komoditas ini di Provinsi NTB dikembangkan sebagai menunjang komoditas kedelai nasional, yang selama ini masih dilakukan impor. Penelitian ini dilakukan di Kabupaten Bima, sebagai salah satu wilayah kabupaten di Provinsi NTB yang berpotensi dalam pengembangan komoditas kedelai. Penelitian ini bertujuan untuk memetakan kelas kesesuaian lahan dalam pengembangan tanaman pangan, terutama tanaman kedelai (glycine max L merril) di Kabupaten Bima. Penelitian ini berguna sebagai bahan informasi dan rekomendasi terkait kesesuaian lahan serta dapat dijadikan dasar pengembangan budidaya tanaman kedelai pada lahan kering. Metode penelitian yang digunakan yaitu metode survei dan metode pengumpulan data sekunder berupa peta dan data spasial dari instansi yang terkait. Pengelompokan kelas kesesuaian lahan pada setiap unit lahan menggunakan sistim overlay atau tumpang tepat dengan berpedoman pada kriteria kesesuaian lahan tanaman kedelai. Hasil penelitian menunjukkan bahwa kelas kesesuaian lahan kering actual, pada kelas cukup sesuai (S2) adalah seluas 3.244,20 ha dengan prosentase sebesar 20,12\%; kelas kesesuaian lahan kering sesuai marginal (S3) seluas $28.108,12$ ha dengan prosentase $78,43 \%$; dan kelas kesesuaian lahan tidak sesuai (N) sebesar 744 ha dengan prosentase paling kecil yaitu 1,45\%. Dengan demikian, potensi lahan kering untuk pengembangan tanaman kedelai (glycine max $L$ merril) di Kabupaten Bima sangat besar yaitu $31.352,32$ ha.
\end{abstract}

\begin{abstract}
West Nusa Tenggara (NTB) Province, is one of 3 provinces in Indonesia as a producer of soybean commodity. This commodity in NTB Province was developed to support the national soybean commodity, which has been still imported. This research was conducted in Bima Regency as one of the districts in NTB Province which has the potential for developing soybean commodities. This study aims to map land suitability classes for the development of food crops, especially soybean (glycine max (L.) Merrill) in Bima Regency. This research is useful as information and recommendations related to land suitability and can be used as a basis for developing soybean cultivation on dry land. The research method used is the survey method and secondary data collection methods such as maps and spatial data from related agencies. Classification of land suitability classes for each land unit uses an overlay or overlapping system based on criteria of the land suitability for soybean crops. The results showed that suitability class of dry land quite suitable (S2) is 3,244.20 ha with a percentage of 20.12\%; suitability class of dry land marginally suitable (S3) covering an area of $28,108.12$ ha with a percentage of $78.43 \%$; and unsuitable land suitability class (N) is 744 ha with the smallest percentage of $1.45 \%$. Therefore, the potential of dry land for the development of soybean crop (Glycine max (L.) Merrill) in Bima is very large, that is $31,352.32$ ha or $98.55 \%$ of the total dry land in Bima Regency.
\end{abstract}

\section{A. LATAR BELAKANG}

Berdasarkan data tahun 2019, kebutuhan kedelai nasional mencapai 3,5 juta ton pertahun, sementara produksi dalam negeri baru mencapai 700 ribu hingga 800 ribu ton kedelai pertahun. Dengan demikian indonesia masih kekurangan 2,7 juta hingga 2,8 juta ton kedelai setiap tahunnya. Kekurangan tersebut terpaksa dipenuhi melalui impor, sehingga kebijakan pemerintah saat ini mendorong berbagai daerah di Indonesia untuk meningkatkan produksi kedelai, guna mencapai swasembada kedelai sebagai salah satu target pemerintah Indonesia [ 1] 
Provinsi Nusa Tenggara Barat (NTB) merupakan provinsi dengan urutan ke 3 setelah Jawa Timur dan Jawa Tengah sebagai penghasil terbesar komoditas kedelai Nasional 2]. Potensi komoditas kedelai di provinsi NTB jika dilihat target produksi nasional memiliki proporsi jumlah yang cukup besar walaupun secara produksi terjadi fluktuasi pada tiap tahunnya. Ini ditunjukkan oleh data perkembangan luas panen, produktivitas dan jumlah produksi kedelai di Provinsi NTB, dalam 7 Tahun terakhir.

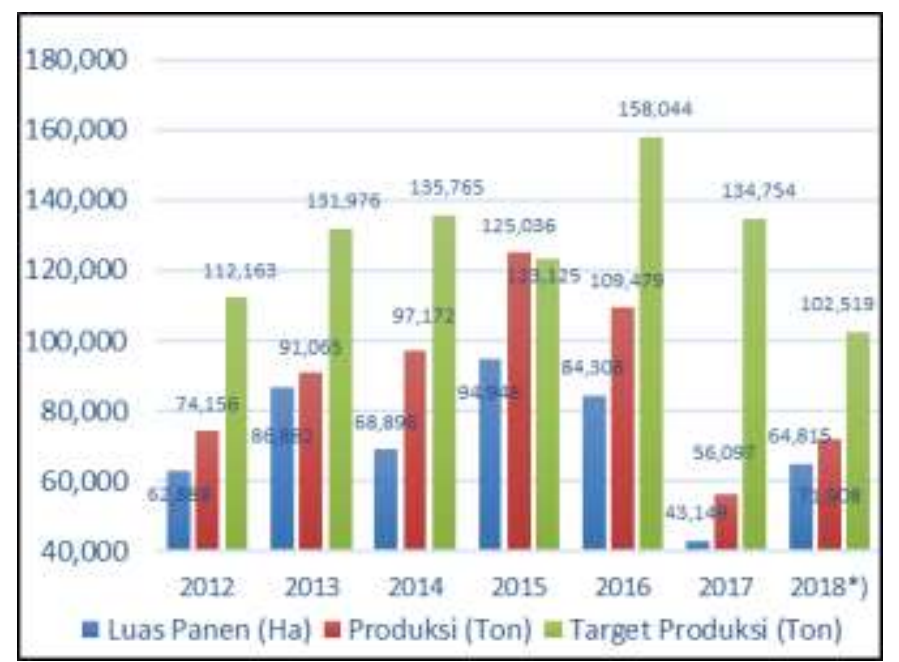

Gambar 1. Grafik Perkembangan Produksi Kedelai Nusa Tenggara Barat, 2012-2018

Dari data perkembangan 3 (tiga) aspek tersebut, adanya kesenjangan antara target produksi yang telah ditetapkan, dengan produksi komoditas yang dihasilkan. Terlihat adanya gap antara jumlah Target produksi dengan hasil produksi yang dihasilkan. Salah satu wilayah di provinsi NTB, yang memiliki potensi pengembangan tanaman komoditas pertanian adalah Kabupaten Bima. Sejak lama kabupaten ini sebagai menyokong stabilitas pangan yang ada di wilayah provinsi NTB. Sebaran lahan yang ada di Kabupaten Bima, masuk dalam pertumbuhan wilayah potensial, dimana diperoleh berdasarkan nilai sistem produksi dan nilai potensi. Adapun yang termasuk pada nilai sistem produksi adalah produksi (UMKM, IBM, angkatan kerja, dan usaha pariwisata), trasaksi (sarana perdagangan dan niaga), dan transformasi (tenaga kerja sektor primer dan tenaga kerja sektor non primer), sedangkan yang termasuk nilai potensi adalah potensi Sumber Daya Alam (perikanan, pertanian, peternakan, wisata, kerawanan bencana, dan kesesuaian lahan), potensi Sumber Daya Manusia (tingkat pendidikan, partisipasi masyarakat dalam lembaga ekonomi, jumlah kelompok tani, dan penduduk usia produktif), infrastruktur (jalan, sarana pendidikan, sarana kesehatan, prasarana listrik, dan prasarana air), dan pendanaan (alokasi dana desa) [3].

Kabupaten Bima memiliki 68,7\% lahan kering yang tersebar di 18 kecamatan, dengan tingkat curah hujan sangat rendah yaitu 250-750 mm setiap tahunnya. Optimalisasi fungsi lahan kering masih terus dilakukan terutama terkait pemanfaatan lahan kering untuk pengembangan tanaman pangan, tanpa memperhatkan kesesuaian lahan dan terjadi sampai saat ini. Kesesuaian lahan untuk lahan pertanian penting untuk diketahui dengan cara membandingkan persyaratan tumbuh tanaman dengan kondisi lahan. Kesesuaian lahan adalah kecocokan suatu lahan untuk penggunaan tertentu. Kesesuaian lahan akan lebih spesifik bila ditinjau dari sifat- sifat fisik lingkungan seperti iklim, tanah, topografi, hidrologi dan drainase yang sesuai untuk usaha tani tanaman tertentu yang produktif [4]. Kelas kesesuaian suatu areal dapat berbeda tergantung daripada tipe penggunaan lahan yang sedang dipertimbangkan [ 5 ]. Untuk mendapatkan kesesuaian suatu lahan terhadap suatu komoditas tanaman maka dilakukan evaluasi lahan. Kesesuaian lahan mencakup dua hal penting, yaitu kesesuaian aktual dan potensial 6].

Topografi Kabupaten Bima berdasarkan kelerengan lahannya dapat diklasifikasikan sebagai berikut 0-2 \%, 2-5\%, 5-15\%, 15-40\% dan lebih besar dari 40\% tersebar di seluruh wilayah Kabupaten Bima. Sedangkan berdasarkan ketinggian diklasifikasikan o200 mdpl, 200-500 mdpl, 500-1500 mdpl dan 15003000 mdpl. Dengan kemiringan dan ketinggian tersebut maka luas lahan kering di Kabupaten Bima tercatat 51.220,88 ha yang terdiri dari hutan belukar, kebun campuran, padang, perkampungan, tanah terbuka dan tegalan/ladang [7].

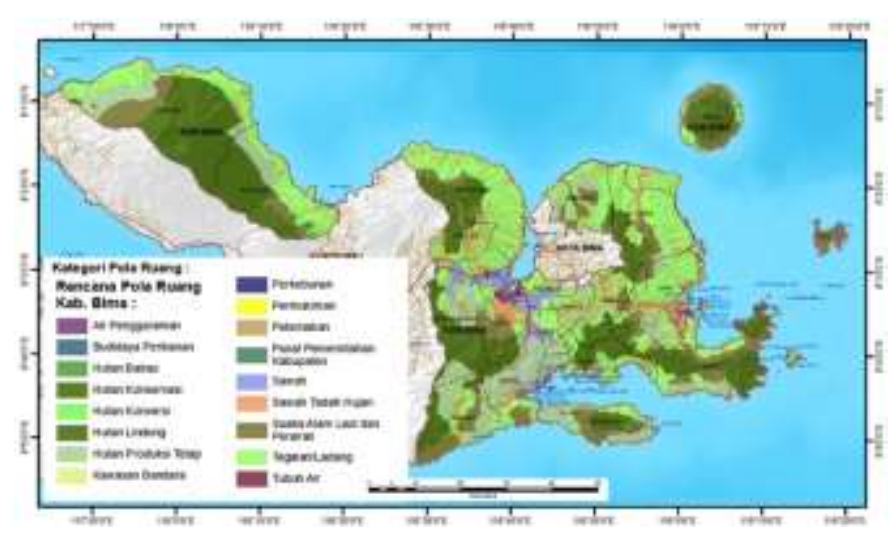

Gambar 2. Peta Kategorisasi Pola Ruang Kabupaten Bima

Penelitian ini bertujuan memetakan potensi lahan kering untuk pengembangan tanaman kedelai serta usahausaha perbaikan yang perlu dilakukan untuk meningkatkan hasil produksi tanaman kedelai. Melalui kegiatan ini diharapkan petani di Kabupaten Bima dapat mengembangkan komoditas kedelai sesuai dengan potensi lahan kering yang telah dievaluasi. Manfaat selanjutnya adalah produksi yang diperoleh dapat meningkat dan pada akhirnya dapat meningkatkan perekonomian masyarakat dengan tetap memperhatikan daya dukung lahan.

\section{B. METODE PENELITIAN}

Penelitian ini dilaksanakan di Kabupaten Bima, Provinsi NTB, dimana kabupaten ini memiliki potensi 
lahan yang luas dan terkategori sebagai lahan pertanian yang dapat dikembangkan sebagai lahan komoditas kedelai. Alat analisis yang digunakan dalam penelitian ini adalah pendekatan dengan melakukan overlay (tumpang susun) peta, yang berasal dari penggabungan dari parameter-parameter peta-peta tematik tertentu yang memiliki informasi spesifik. Overlay dilakukan dengan bantuan perangkat lunak ESRI ArcGIS v.10 dan didukung dengan GPS (Global Positioning System) sebagai petunjuk posisi atau letak lahan kering di daerah penelitian.

Metode yang digunakan yaitu metode survey dan metode pengumpulan data sekunder berupa peta dan data spasial dari instansi yang terkait8]. Kriteria penentuan kelas kesesuaian lahan menggunakan kriteria kesesuaian lahan berdasarkan kualitas dan karakteristik lahan yang dibagi menjadi 3 (tiga) kelas yaitu (S1) sangat sesuai, (S2) cukup sesuai, (S3) sesuai marginal dan tidak sesuai (N) [ 9 ], standar kelas kesesuaian lahan ini akan dioverlay atau tumpang susun dengan peta kelompok lahan eksisting, sehingga menghasilkan peta akhir kesesuaian lahan untuk tanaman kedelai.

Tabel 1.

Kelas Kesesuaian Lahan Berdasarkan Kualitas dan Karakteristik Lahan

\begin{tabular}{|c|c|c|c|}
\hline \multicolumn{4}{|c|}{ Kelas Kesesuaian Lahan } \\
\hline $\begin{array}{l}\text { S1 (Sangat } \\
\text { Sesuai) }\end{array}$ & $\begin{array}{c}\text { S2 (Cukup } \\
\text { Sesuai) }\end{array}$ & $\begin{array}{l}\text { S3 (Sesuai } \\
\text { Marginal) }\end{array}$ & $\begin{array}{c}\text { N (Tidak } \\
\text { Sesuai) }\end{array}$ \\
\hline $\begin{array}{c}\text { Lahan tidak } \\
\text { mempunyai } \\
\text { faktor } \\
\text { pembatas } \\
\text { yang berarti } \\
\text { atau nyata } \\
\text { terhadap } \\
\text { penggunaan } \\
\text { secara } \\
\text { berkelanjutan, } \\
\text { atau faktor } \\
\text { pembatas } \\
\text { yang bersifat } \\
\text { minor dan } \\
\text { tidak akan } \\
\text { mereduksi } \\
\text { produktivitas } \\
\text { lahan secara } \\
\text { nyata. }\end{array}$ & $\begin{array}{c}\text { Lahan } \\
\text { mempunyai } \\
\text { faktor pembatas, } \\
\text { dan faktor } \\
\text { pembatas ini } \\
\text { akan } \\
\text { berpengaruh } \\
\text { terhadap } \\
\text { produktivitasnya, } \\
\text { memerlukan } \\
\text { tambahan } \\
\text { masukan (input). } \\
\text { Pembatas } \\
\text { tersebut biasanya } \\
\text { dapat diatasi } \\
\text { oleh petani } \\
\text { sendiri. }\end{array}$ & $\begin{array}{c}\text { Lahan } \\
\text { mempunyai } \\
\text { faktor pembatas } \\
\text { yang berat, dan } \\
\text { faktor pembatas } \\
\text { ini akan } \\
\text { berpengaruh } \\
\text { terhadap } \\
\text { produktivitasnya, } \\
\text { memerlukan } \\
\text { tambahan } \\
\text { masukan yang } \\
\text { lebih banyak } \\
\text { daripada lahan } \\
\text { yang tergolong } \\
\text { S2. Untuk } \\
\text { mengatasi faktor } \\
\text { pembatas pada } \\
\text { S3 memerlukan } \\
\text { modal tinggi, } \\
\text { sehingga perlu } \\
\text { adanya bantuan } \\
\text { atau campur } \\
\text { tangan } \\
\text { (intervensi) } \\
\text { pemerintah atau } \\
\text { pihak swasta. } \\
\text { Tanpa bantuan } \\
\text { tersebut petani } \\
\text { tidak mampu } \\
\text { mengatasinya. }\end{array}$ & $\begin{array}{c}\text { Lahan yang } \\
\text { tidak sesuai } \\
(\mathrm{N}) \text { karena } \\
\text { mempunyai } \\
\text { faktor } \\
\text { pembatas } \\
\text { yang sangat } \\
\text { berat } \\
\text { dan/atau } \\
\text { sulit } \\
\text { diatasi. }\end{array}$ \\
\hline
\end{tabular}

Sumber : BBSDLP, 2013

Penilaian kelas kesesuaian lahan tanaman kedelai disajikan dalam bentuk data dan peta untuk masingmasing kriteria kesesuaian. Parameter kesesuaian lahan berdasarkan petunjuk teknis (Kementerian Pertanian,
2016), maka terdapat tujuh tema peta karakteristik lahan untuk kedelai.

Tabel 2.

Kriteria Penentuan Kelas Kesesuain Lahan Untuk Tanaman Kedelai

\begin{tabular}{llccccc}
\hline No & Kualitas/Karakter & Sim & \multicolumn{4}{c}{ Kelas Kesesuaian Lahan/Kriteria } \\
\cline { 5 - 7 } & istik Lahan & bol & S1 & S2 & S3 & N \\
\hline $\mathbf{1}$ & Temperatur & (t) & & & & \\
\hline & Rata-rata tahunan & & $23-25$ & $>25-28$ & $>28-$ & $>32$ \\
& $\left({ }^{\circ} \mathrm{C}\right)$ & & & 32 & \\
\hline & & & & $20-<23$ & $18-$ & $<18$ \\
& & & & & & \\
& & & & & &
\end{tabular}

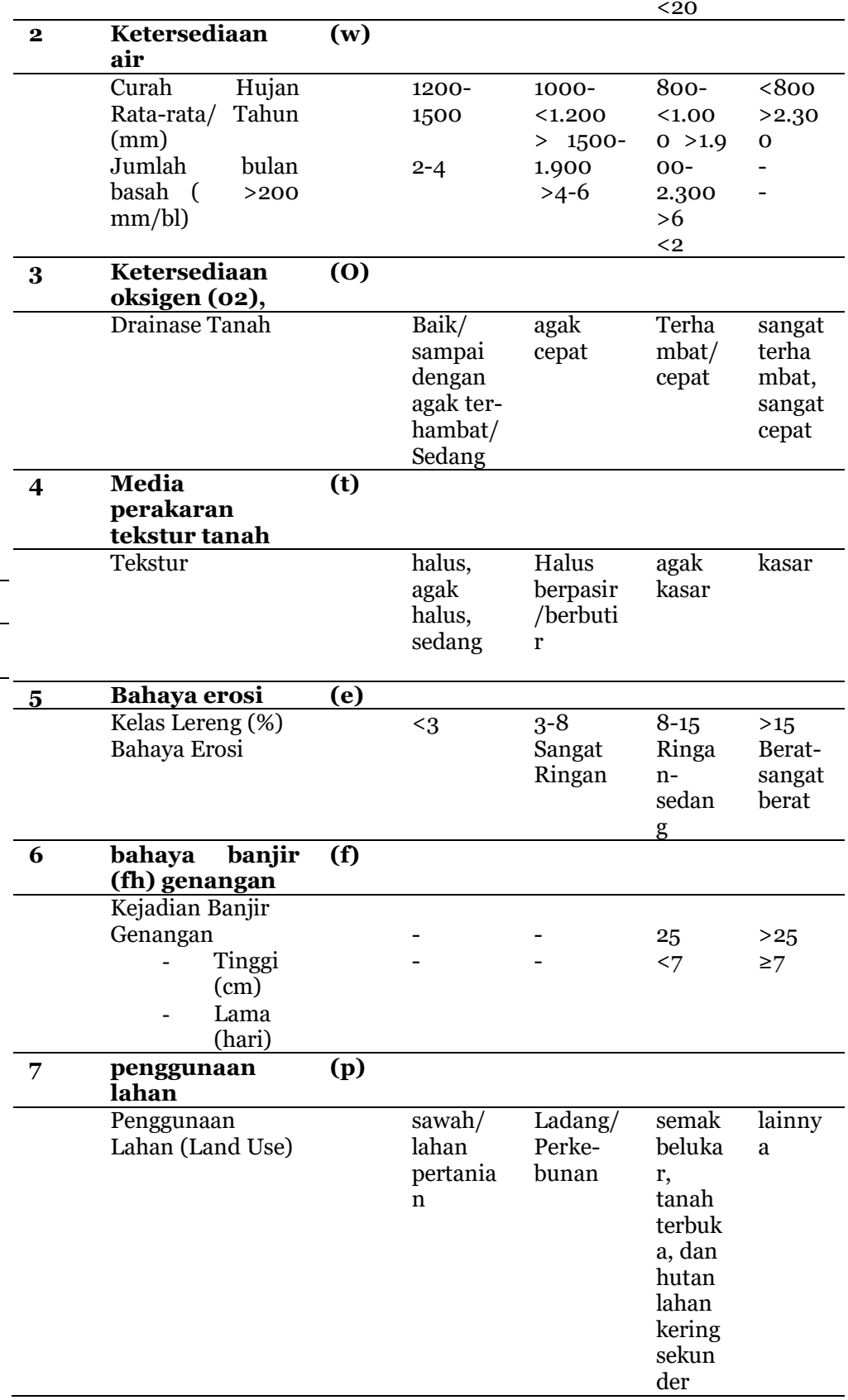

Sumber : BBSDLP, 2013

Analisis data dilakukan dengan 6 (enam) tahapan sebagai berikut :

1. Data dalam bentuk peta kriteria kesesuain lahan kedelai yang terdiri dari peta temperatur, peta ketersediaan air, ketersediaan oksigen, media perakaran tekstur tanah, peta bahaya erosi dan peta 
45 | Jurnal Planoearth | Vol. VI, No. I, Februari 2021, hal 42-48

bahaya banjir akan dioverlay dengan peta lahan kering dan peta penggunaan lahan.

2. Peta dibuat berdasarkan tema untuk mengetahui luas, sebaran dan persentase lahan kering yang dapat dimanfaatkan untuk optimalisasi produksi tanaman kedelai.

3. Penilaian dilakukan dengan penambahan field atau keterangan klasifikasi dan pemberian kodefikasi pada data atribut hasil overlay menggunakan tools field calculator pada program ArcGis dan untuk menghitung luas masing - masing kelas kesesuaian lahan digunakan tools calculate geometri.

4. Overlay batas wilayah dengan masing-masing tema karakteristik lahan menghasilkan tujuh tema peta kesesuaian lahan, seluruh tema tersebut dioverlay kembali dengan peta lahan kering dan peta penggunaan lahan.

5. Sebaran kelas kesesuaian lahan kering untuk tanaman kedelai secara actual telah diperoleh. Penilaian kelas kesesuaian lahan pada tahap ini menggunakan hukum minimum yaitu mencocokkan antara kualitas lahan kering atau karakteristik lahan kering sebagai parameter dengan kriteria kelas kesesuaian lahan kering yang telah disusun berdasarkan persyaratan penggunaan atau persyaratan tumbuh tanaman kedelai.

6. Tahapan akhir yaitu rekomendasi alokasi penggunaan lahan kering di Kabupaten Bima yang termasuk dalam kelas kesesuaian lahan cukup sesuai (S2) dan lahan sesuai marginal $\left(\mathrm{S}_{3}\right)$ berdasarkan faktor pembatas masing-masing lahan kering yang tersebar, sehingga mampu diarahkan untuk pengembangan budidaya tanaman kedelai dalam rangka peningkatan produktivitas kedelai, dan untuk kesesuaian lahan tidak sesuai $(\mathrm{N})$ diarahkan untuk mampu memperbaiki kualitas lahan kering sehingga menjamin tidak terjadinya alih fungsi lahan dan dapat tetap dipastikan keberadaannya untuk digunakan sebagai lahan pertanian berkelanjutan.

\section{HASIL DAN PEMBAHASAN}

Lahan kering di Kabupaten Bima belum menjadi prioritas utama penanganan bidang pertanian, sedangkan 24\% wilayah Kabupaten Bima adalah lahan kering (Dinas Pertanian Kab.Bima, 2018) yang tersebar di 18 kecamatan yaitu Kecamatan Sape, Kecamatan Lambu, Kecamatan Wawo, Kecamatan Lambitu, Kecamatan Wera, Kecamatan Ambalawi, Kecamatan Palibelo, Kecamatan Belo, Kecamatan Woha, Kecamatan Monta, Kecamatan Langgudu, Kecamatan Parado, Kecamatan Bolo, Kecamatan Madapangga, Kecamatan Donggo, Kecamatan Soromandi, Kecamatan Sanggar dan Kecamatan Tambora serta terdapat 191 desa. Berdasarkan 7 kriteria penentuan kesesuaian lahan untuk tanaman kedelai yaitu temperatur, ketersediaan air, ketersediaan oksigen, media perakaran tekstur tanah, bahaya erosi, bahaya banjir dan jumlah genangan serta penggunaan lahan pada masing-masing kecamatan, telah dilakukan analisis kesesuaian lahan kering terhadap masing-masing kecamatan.

Tabel 3.

Sebaran Luas Lahan Kering Di Kabupaten Bima, 2016

\begin{tabular}{clr}
\hline No & \multicolumn{1}{c}{ Kecamatan } & Luas (ha) \\
\hline 1 & Ambalawi & $2.044,08$ \\
2 & Belo & 337,92 \\
3 & Bolo & $2.626,43$ \\
4 & Donggo & 975,07 \\
5 & Lambitu & 187,14 \\
6 & Lambu & $8.537,95$ \\
7 & Langgudu & $3.842,78$ \\
8 & Madapangga & $3.312,93$ \\
9 & Monta & $1.681,22$ \\
10 & Palibelo & 413,52 \\
11 & Parado & 603,18 \\
12 & Sanggar & $3.209,27$ \\
13 & Sape & $2.653,01$ \\
14 & Soromandi & $7 \cdot 580,61$ \\
15 & Tambora & $9.199,17$ \\
16 & Wawo & 937,50 \\
17 & Wera & $6.271,75$ \\
18 & Woha & 393,97 \\
\hline Sumber : BBSDLP,2O16
\end{tabular}

1. Kesesuaian Lahan Terhadap Temperatur (t)

Rata-rata suhu udara baik malam maupun siang hari di Kabupaten Bima adalah $22-33{ }^{\circ} \mathrm{C}$ terdiri dari 9 kecamatan yaitu Kecamatan Ambalawi, Kecamatan Belo, Kecamatan Bolo, Kecamatan Donggo, Kecamatan Palibelo, Kecamatan Sape, Kecamatan Wawo, Kecamatan Wera dan Kecamatan Woha sehingga secara temperatur 9 kecamatan tersebut masuk kriteria tidak sesuai untuk tanaman kedelai, sedangkan berdasarkan kriteria kelas kesesuaian lahan menurut kualitas temperatur atau suhu berada pada kisaran $22^{\circ} \mathrm{C}-32^{\circ} \mathrm{C}$, terdiri dari 9 kecamatan juga yaitu Kecamatan Lambitu, Kecamatan Lambu, Kecamatan Langgudu, Kecamatan Madapangga, Kecamatan Monta, Kecamatan Parado, Kecamatan Sanggar, Kecamatan Soromandi dan Kecamatan Tambora termasuk kedalam kelas sesuai marginal (S3).

2. Kesesuaian Lahan Terhadap Kesediaan Air (w) Klasifikasi curah hujan rata-rata pertahun berkisar antara 250-750 mm/tahun, 750-1250 $\mathrm{mm} /$ tahun dan 1250-1750 mm/tahun namun sebagian besar wilayah Kabupaten Bima didominasi oleh klasifikasi curah hujan 250-750 mm/tahun dalam 125 titik curah hujan tersebar di 18 kecamatan. Berdasarkan klasifikasi diatas dengan curah hujan 250-750 $\mathrm{mm} /$ tahun tersebut tidak sesuai untuk 
dikembangkan tanaman kedelai $(\mathrm{N})$, sedangkan terdapat 57 titik curah hujan 1250-1750 mm/tahun masuk dalam kriteria sesuai marginal dan $\mathrm{S}_{3}$ titik curah hujan 750-1250 mm/tahun masuk kriteria sangat sesuai (S1). Keadaan Curah hujan yang tinggi cenderung menambah kecepatan pelapukan dan pembentukan liat dan secara tidak langsung mempengaruhi reaksi tanah. Selain itu juga dapat mengakibatkan pencucian kation basa dari lapisan permukaan tanah ke lapisan tanah yang lebih dalam sehingga $\mathrm{pH}$ tanah akan menjadi masam (Wirosoedarmo, et al., 2011).

\section{Kesesuaian Lahan Terhadap Ketersediaan Oksigen (o)}

Ketersediaan oksigen diukur dengan melihat kondisi drainase, dimana kondisi drainase ditinjau dari lama genangan, jika lama genangan air kurang dari 1 jam adalah kondisi drainase terbaik (Kementerian Pekerjaan umum, 2014), hasil analisis menunjukkan bahwa di Kabupaten Bima terdapat 46 titik dengan kondisi drainase cepat sehingga masuk dalam kriteria tidak sesuai (N) dengan total luas $336.857,56$ ha atau 41,9\% sedangkan 15 titik masuk dalam kriteria drainase baik (S1) dengan luas $64.854,98$ ha atau $9,1 \%$.

\section{Kesesuaian Lahan Terhadap Media perakaran tekstur tanah (t)}

Media perakaran yang dimaksud disini adalah tanah sebagai media pertumbuhan tanaman. Tekstur tanah yang paling sesuai bagi tanaman kedelai adalah tekstur yang halus atau tanah lempung (Sudjana et al., 1991). Berdasarkan hasil analisis klasifikasi kelas kesesuaian lahan menurut klasifikasi tekstur tanah di Kabupaten Bima menunjukkan kelas kesesuaian lahan sangat sesuai ( $\mathrm{S} 1$ ) seluas 28380,60 ha $(7,06 \%)$, cukup sesuai (S2) seluas 552,80 ha $(0,13 \%)$ dan sesuai marginal (S3) seluas 372779,6 Ha (92,79\%).

\section{Kesesuaian Lahan Terhadap Bahaya Erosi (e)}

Berdasarkan analisis kelerengan, diperoleh luas lahan yang termasuk kelas sangat sesuai (S1) kategori lereng $0-8 \%$ mencapai 38163,75 ha atau sebesar 9,5\% dari luas lahan kering di Kabupaten Bima. Lahan dengan kelas sesuai marginal (S3) seluas 3991,42 ha atau sebesar $0,9 \%$ dan lahan dengan kelas tidak sesuai seluas 357994,66 Ha atau sebesar 89,26\%.

\section{Kesesuaian Lahan Terhadap Banjir Genangan} (f)

Lahan pertanian mengalami banjir genangan umumnya akibat luapan air sungai, luapan air sungai tersebut ada yang kemudian langsung surut mengalir ke laut dan sebagian terinfiltrasi kedalam tanah. Air yang tertinggal yang tidak mengalir dan teresap bertahan lebih lama berlangsung selama beberapa hari mengakibatkan genangan pada lahan kering. Berdasarkan hasil analisis pada program ArcGis menunjukkan luas wilayah yang mengalami banjir genangan kurang dari satu bulan atau banjir yang terjadi degan kategori ringan sehingga berdasarkan kelas kesesuainnya termasuk kelas cukup sesuai (S2) seluas 845 ha atau hanya mencapai 3,4\% dari total luas wilayah yang tidak mengalami banjir genangan dalam satu tahun, sehingga hasil analisis luas wilayah yang termasuk kelas kesesuaian lahannya sangat sesuai (S1) mencapai 23.886 ha $(96,6 \%)$.

\section{Kesesuaian Lahan Terhadap Penggunaan Lahan}

Hasil analisis kesesuaian lahan kering yang terdiri dari hutan belukar, hutan lebat, kebun campuran, padang, perairan darat, perkampungan, perkebunan, tanah terbuka dan tegalan/ladang untuk tanaman kedelai berdasarkan kriteria penggunaan lahan di Kabupaten Bima menunjukkan bahwa pada umumnya wilayah Kabupaten Bima termasuk kelas sesuai marginal $\left(\mathrm{S}_{3}\right)$ dan cukup sesuai (S2), terdapat beberapa lokasi yang tidak sesuai berdasar kriteria penggunaan lahan dimana lokasi tersebut merupakan areal pemukiman dan perairan darat. Hasil olahan analisis spasial pada program ArcGis menunjukkan klas (S3) seluas 43675 ha $(80,77 \%)$, kelas cukup sesuai (S2) seluas 9463,22 ha (17,50\%), dan kelas tidak sesuai (N) seluas 931,29 ha (1,72\%).

\section{Analisis Kesesuaian Lahan Aktual}

Analisis seluruh kriteria dalam hal ini digunakan 7 tema karakteristik lahan sebagaimana telah dibahas sebelumnya yaitu menentukan kesesuaian lahan aktual untuk tanaman kedelai di Kabupaten Bima menggunakan peta dasar dikhususkan pada lahan kering, sebaran lahan kering mencapai 98,43 \% terdiri dari hutan belukar, kebun campuran, padang, perkampungan, tanah terbuka dan tegalan atau ladang. Dibandingkan dengan total keseluruhan lahan di Kabupaten Bima lahan kering sangat mendominasi hampir keseluruhan wilayah.

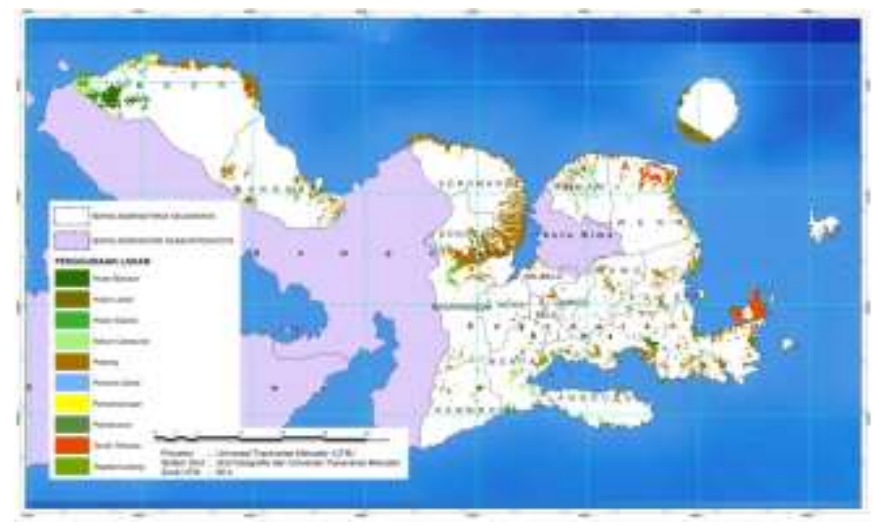

Gambar 3. Peta Sebaran Lahan Kering di Kabupaten Bima 


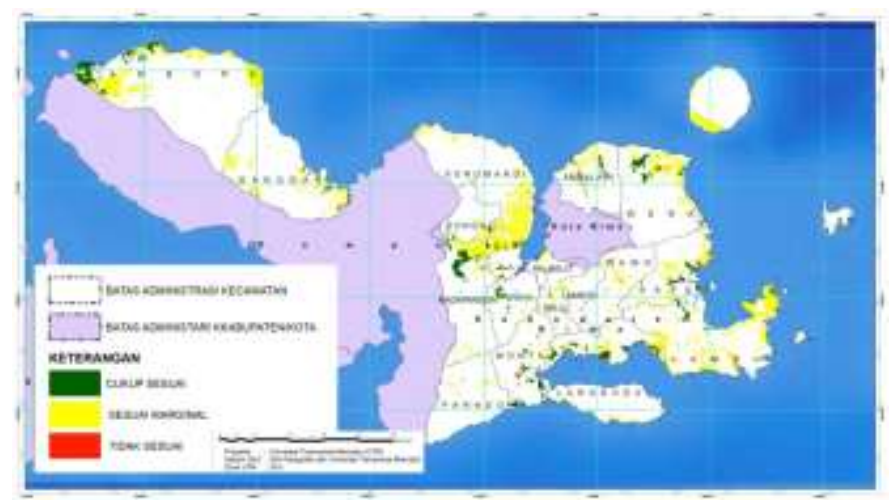

Gambar 4. Peta Kelas Kesesuaian Lahan Kering Aktual di Kabupaten Bima

Hasil analisis terhadap seluruh kriteria tersebut menunjukkan bahwa kelas kesesuaian lahan di daerah penelitian didominasi oleh kelas sesuai marginal ( 33 ). Berdasarkan hasil analisis lahan cukup sesuai (S2) seluas $3.244,20$ ha (20\%) yang tersebar di 4 kecamatan yaitu Kecamatan Langgudu, Kecamatan Madapangga, Kecamatan Wera dan Kecamatan Tambora, sedangkan sesuai marginal (S3) seluas $28.108,12$ ha $(78,43 \%)$ yang terdiri dari Kecamatan Tambora, Kecamatan Langgudu, Kecamatan Madapangga, Kecamatan lambu, Kecamatan Langgudu, Kecamatan Wera dan tidak sesuai (N) seluas 744 ha $(1,45 \%)$ di Kecamatan Sape, Kecamatan Monta dan Kecamatan Langgudu. Data kelas kesesuaian lahan untuk tanaman kedelai di Kabupaten Bima dirinci per kecamatan.

Tabel 4.

Data Kelas Kesesuaian Lahan Aktual Dirinci Per-kecamatan Di Kabupaten Bima

\begin{tabular}{ccccc}
\hline \multirow{2}{*}{ No } & \multirow{2}{*}{ Kecamatan } & \multicolumn{3}{c}{ Kriteria Kesesuain Lahan } \\
\cline { 3 - 5 } & & $\mathrm{S} 2$ & $\mathrm{~S} 3$ & $\mathrm{~N}$ \\
\hline 1 & Ambalawi & 467,99 & $1.292,60$ & 8 \\
2 & Belo & 34,03 & 278,48 & 38,38 \\
3 & Bolo & 371,73 & 2425 & 36,05 \\
4 & Donggo & 220,28 & 736,98 & - \\
5 & Lambitu & - & 81,00 & - \\
6 & Lambu & 394,77 & $7.064,24$ & 48,20 \\
7 & Langgudu & $1.069,95$ & $2.326,81$ & 165,41 \\
8 & Madapangga & $1.425,92$ & $1.999,69$ & 15,96 \\
9 & Monta & 977,03 & 577,30 & 142,56 \\
10 & Palibelo & 126,39 & 333,10 & 16,60 \\
11 & Parado & 47,67 & 537,18 & 0,01 \\
12 & Sanggar & 467,46 & $2.569,30$ & 5,24 \\
13 & Sape & 681,27 & $2.127,17$ & 116,43 \\
14 & Soromandi & 25,88 & $5.213,50$ & - \\
15 & Tambora & $2.475,21$ & $6.642,45$ & 38,63 \\
16 & Wawo & 21,60 & 880,84 & 29,71 \\
17 & Wera & $1.069,43$ & $4.753,69$ & 81,68 \\
18 & Woha & 418,58 & 318,93 & 1,21 \\
\hline
\end{tabular}

Sumber : Hasil Interpretasi dan Pengolahan Penulis, 2020

\section{Analisis Kesesuaian Lahan Faktual}

Luas tanam kedelai Kabupaten Bima pada Tahun 2019 adalah 29.091 ha dengan luas panen 29.091 ha (Dinas Pertanian,2020), luas panen tersebut tersebar di 18 kecamatan. Total luas lahan yang digunakan adalah luas lahan basah ditambah luas lahan kering. Peta lahan kering dioverlay dengan peta kelas kesesuaian lahan actual, sehingga mendapatkan hasil lahan usaha tani kedelai yang diklasifikasikan sesuai kelas kesesuaian lahan yaitu lahan tidak sesuai $(\mathrm{N})$ yaitu seluas 744 ha atau 1,86\% yang tesebar di 3 kecamatan dengan luasan terbesar yaitu Kecamatan Sape, Kecamatan Langgudu dan Kecamatan Monta, sedangkan yang diusahakan di kelas kesesuaian lahan sesuai marjinal ( $\mathrm{S}_{3}$ ) seluas $40.158,22$ ha atau $65,47 \%$ tersebar di 3 Kecamatan yaitu Tambora, Kecamatan Lambu dan Kecamatan Soromandi, untuk kelas kesesuaian lahan cukup sesuai (S2) seluas 10.295,20 ha atau $25,73 \%$.

\section{SIMPULAN DAN SARAN}

\section{Kesimpulan}

Lahan kering adalah kawasan dengan daya dukungnya terhadap kehidupan dan kesejahteraan hidup manusia. Sumber daya lahan kering berpotensi besar dalam pembangunan berkelanjutan dan mempunyai layanan ekosistem penting antara lain penyedia pangan, sandang, pakan, kayu dan air. Dengan memetakan kesesuaian lahan, terutama lahan kering, maka akan diketahui sejauh mana tingkat kesesuaian lahan tersebut, berdasarkan kriteria-kriteria yang telah dietetapkan, sebagai penunjang dan pendukung komoditas kedelai.

Kelas kesesuaian lahan aktual tanaman kedelai terdapat 2 (dua) kelas yaitu kelas sesuai marjinal (S3) seluas $28.108,12$ ha atau $65,47 \%$ dan kelas kesesuaian lahan cukup sesuai (S2) seluas 3.244,20 ha atau 20\%, setelah dilakukan usaha perbaikan lahan pengembangan tanaman kedelai, maka kelas kesesuaian lahan potensial menjadi kelas kesesuaian lahan sesuai marjinal $\left(\mathrm{S}_{3}\right)$ seluas 40.158,22 ha atau 65,47\% kelas kesesuaian lahan cukup sesuai (S2) seluas $10.295,20$ ha atau $25,73 \%$.

\section{Saran}

Disarankan kepada pihak pengembang atau pengguna lahan untuk melakukan pengelolaan lahan yang optimal sesuai dengan kelas kesesuaian lahan yang telah didapatkan, dan pemerintah selaku pengambil kebijakan penuh sebaiknya memberikan arahan penggunaan lahan sesuai hasil kajian akademis yang telah disusun 


\section{DAFTAR RUJUKAN}

[1] Andayanie Ria Wuye, Pengembangan Produksi Kedelai Sebagai Upaya Kemandirian Pangan Di Indonesia. Jakarta: Mitra Wacana Media, 2016.

[2] Badan Pusat Statistik, "Kabupaten Bima Dalam Angka 2019," Bima, 2019.

[3] Fariz Primadi Hirsan dkk, "Kajian Kawasan Strategis Cepat Tumbuh Kabupaten Bima," Jurnal PlanoEarth, vol. Vol. 4, No. 1, no. ISSN 2502-5031, pp. 31-42, Februari 2019.

[4] M. Luthfi Rayes, Metode Inventarisasi Sumber Daya Lahan. Yogyakarta, Indonesia: Andi, 2007.

[5] Santun RP Sitorus, Evaluasi Sumberdaya Lahan, 3rd ed. Bandung, Indonesia: Tarsito, 1985.

[6] Widiatmaka Sarwono H, Evaluasi Kesesuaian Lahan \& Perencanaan Tata Guna Lahan, 2nd ed. Yogyakarta, Indonesia: Gadjah Mada University Press, 2011.

[7] Badan Perencanaan Pembangunan \& Penelitian Pengembangan, "Buku Laporan Analisis Kesesuaian Lahan Untuk Tanaman Kedelai," Pemerintah Kabupaten Bima, Bima, Laporan Tahunan 1, 2019.

[8] Delik Hudalah, Petrus N. Indradjati, Dimitra Viantari Nia K.Pontoh, Dasar-dasar Survey Untuk Perencanaan Wilayah \& Kota, 1st ed. Bandung, Indonesia: ITB Press, 2015.

[9] Bayu Pradana dkk, "Analisis Kesesuaian Lahan Pertanian terhadap Komoditas Pertanian Kabupaten Cilacap," Jurnal Geodesi Undip, vol. Vol 2, No. 2, no. ISSN 2337-845, pp. 112, April 2013. 